\title{
PEMBUATAN WEBGIS ZONA NILAI TANAH UNTUK PENGHITUNGAN BPHTB SERTA PPH DALAM JUAL BELI TANAH DAN/ATAU BANGUNAN MENGGUNAKAN GOOGLE MAPS API (STUDI KASUS: KOTA SOLOK, PROVINSI SUMATERA BARAT)
}

\author{
Yanto Budisusanto ${ }^{1}$, Wafa Zakkiyah' ${ }^{2}$, Andy Dediyono ${ }^{3}$ \\ Departemen Teknik Geomatika, FTSLK-ITS, Kampus ITS Sukolilo, Surabaya, 60111, Indonesia \\ e-mail: ${ }^{1}$ yanto_b@geodesy.its.ac.id, ${ }^{2}$ wafa15@geodesy.its.ac.id
}

\begin{abstract}
Abstrak
Kota Solok memiliki peran sentral dalam menunjang perekonomian masyarakat Kota Solok dan Kabupaten Solok pada umumnya. Hal ini menyebabkan Kota Solok mengalami peningkatan jumlah penduduk setiap tahunnya. Peningkatan jumlah jumlah penduduk di Kota Solok berpengaruh terhadap meningkatnya kebutuhan tempat tinggal. Meningkatnya kebutuhan tempat tinggal tersebut berdampak pada meningkatnya Nilai Jual Objek Pajak (NJOP) di Kota Solok. NJOP dapat divisualisasikan menjadi peta zona nilai tanah. NJOP dijadikan dasar dalam menentukan besarnya nilai pajak, salah satunya Bea Perolehan Hak atas Tanah dan Bangunan (BPHTB) serta Pajak Penghasilan (PPh) dalam jual beli tanah dan/atau bangunan. Penelitian ini bertujuan untuk memudahkan Pemda dalam melakukan pembaruan data NJOP yang selanjutnya akan digunakan dalam penghitungan nilai BPHTB dan PPh serta memudahkan masyarakat dan PPAT/Notaris dalam mengetahui nilai BPHTB dan PPh harus dibayarkan pada saat melakukan jual beli tanah dan/atau bangunan. Dari penelitian ini didapatkan bahwa WebGIS zona nilai tanah yang telah dibuat dapat menghitung BPHTB serta PPh, memperbaharui data NJOP, dan menampilkan hasil penghitungan pajak dalam bentuk PDF yang siap dicetak. Besar persentase kelayakan sistem untuk uji usabilitas sebesar 80,38\% dengan predikat layak serta melakukan uji portabilitas dengan mengakses webGIS zona nilai tanah Kota Solok di sepuluh web browser dan berhasil.
\end{abstract}

Kata Kunci: BPHTB, PPh, WebGIS, Zona Nilai Tanah

\begin{abstract}
Solok has a central role in supporting the economical sector of Solok's citizens and Solok District in general. This role causes Solok City experience the increasing number of population every year. The increasing number of residents effects the increasing needs of houses that Tax Object Selling Value (called as NJOP) in Solok City. NJOP which is processed in such ways can be visualized into a map of land value zone. NJOP is used as the basis for determining the amount of tax value, one of which is the Fee for Acquisition of Land and Building Rights (called as BPHTB) and Income Tax (called as PPh) in the sale and purchase of land and/or buildings. This study aims to facilitate local governments in updating NJOP data which will be used in calculating BPHTB and PPh values and facilitating the public and PPAT / Notaries in knowing the BPHTB and PPh values that must be paid when buying or selling land and/or buildings. From this study it was found that WebGIS of land value zones that have been created can be used to calculate BPHTB and PPh, update NJOP data, and show tax calculation results in PDF form that are ready to be printed. The percentage of system feasibility for usability test is $80.38 \%$ with a proper predicate and conducting portability test by accessing webGIS zone of Solok City land value in ten web browsers and successfully ran.
\end{abstract}

Keywords: BPHTB, PPh, WebGIS, Land Value Zone 


\section{PENDAHULUAN}

Wilayah administrasi Kota Solok berbatasan dengan Kabupaten Solok dan Kota Padang. Kota Solok memiliki peran sentral dalam menunjang perekonomian masyarakat Kota Solok dan Kabupaten Solok pada umumnya [1]. Keunggulan geografis ini menyebabkan Kota Solok mengalami peningkatan jumlah penduduk setiap tahunnya. Dengan luas wilayah $57.64 \mathrm{~km}^{2}$, jumlah penduduk Kota Solok pada tahun 2016 sebanyak 67.307 jiwa, dan pada tahun 2017 sebanyak 68.602 jiwa [2]. Peningkatan jumlah penduduk di Kota Solok berpengaruh terhadap meningkatnya kebutuhan tempat tinggal. Meningkatnya kebutuhan tempat tinggal tersebut berdampak pada meningkatnya Nilai Jual Objek Pajak (NJOP) [3]. NJOP dapat divisualisasikan menjadi peta zona nilai tanah.

NJOP dijadikan dasar dalam menentukan besarnya nilai pajak [4]. Salah satunya adalah Bea Perolehan Hak atas Tanah dan Bangunan (BPHTB) serta Pajak Penghasilan (PPh) dalam jual beli tanah dan/atau bangunan. BPHTB merupakan pajak yang dikenakan kepada pembeli, sedangkan PPh merupakan pajak yang dikenakan kepada penjual pada saat jual beli tanah dan/atau bangunan. BPHTB dan PPh dalam transaksi jual beli tanah dan/atau bangunan menjadi penting karena merupakan suatu aktifitas yang dilakukan oleh masyarakat yang dapat memberikan pemasukan berupa pajak dalam jumlah yang relatif besar bagi negara. BPHTB akan dikelola oleh Pemerintah Daerah (Pemda), sedangkan PPh akan dikelola oleh Pemerintah Pusat [5].

BPHTB dan PPh melibatkan banyak pihak, diantaranya Pemda, PPAT/Notaris, dan masyarakat. Pemda mempunyai kewenangan untuk menetapkan besarnya NJOP yang selanjutnya akan dipakai sebagai dasar dalam menghitung besarnya nilai BPHTB dan PPh. PPAT/Notaris memiliki peranan sebagai pejabat umum yang terkait dengan transaksi jual beli tanah dimana PPAT/Notaris akan menandatangani akta otentik setelah pajak BPHTB tersebut dibayar lunas oleh Wajib Pajak. Sedangkan masyarakat merupakan pihak yang wajib membayar BPHTB dan PPh pada saat melakukan jual beli tanah dan/atau bangunan [6].
Saat ini, belum terdapat fasilitas yang dapat memudahkan Pemda dalam melakukan pembaruan data NJOP yang selanjutnya akan digunakan dalam penghitungan nilai BPHTB dan PPh. Dari pihak masyarakat serta PPAT/Notaris, belum terdapat fasilitas untuk memperoleh informasi tentang BPHTB dan PPh secara terbuka, yang dapat mempermudah masyarakat dalam mengetahui nilai BPHTB dan PPh yang harus dibayarkan pada saat melakukan jual beli tanah dan/atau bangunan. Selain itu, belum terdapat WebGIS Zona Nilai Tanah di Kota Solok. Dalam penelitian ini dilakukan pembuatan WebGIS zona nilai tanah dimana Pemda dapat melakukan pembaruan data NJOP dan masyarakat serta PPAT/Notaris dapat mengetahui nilai BPHTB dan PPh yang akan dikenakan saat melakukan jual beli tanah dan/atau bangunan. Dengan adanya WebGIS zona nilai tanah maka akan akan memudahkan Pemda dalam melakukan pembaruan data NJOP dan memudahkan masyarakat serta PPAT/Notaris dalam mengetahui besarnya nilai BPHTB dan PPh yang akan dikenakan pada saat melakukan jual beli tanah dan/atau bangunan. Kegiatan tersebut dapat dilakukan hanya dengan menggunakan perangkat keras, perangkat lunak, serta koneksi jaringan internet untuk mengakses situs dari WebGIS zona nilai tanah.

\section{METODE}

\section{Lokasi Penelitian}

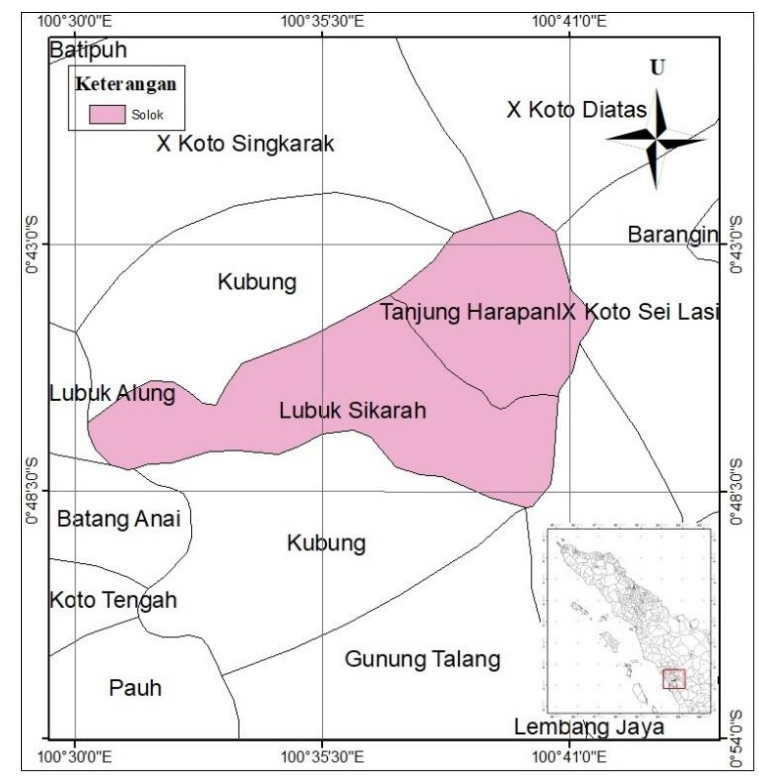

Gambar 1. Lokasi Penelitian 
Lokasi dari penelitian tugas akhir ini adalah Kota Solok, Provinsi Sumatera Barat. Kota Solok terletak pada posisi $0^{\circ} 44^{\prime} 28^{\prime \prime} \mathrm{LU}-0^{\circ} 49^{\prime} 12^{\prime \prime} \mathrm{LS}$, $100^{\circ} 32^{\prime} 42^{\prime \prime}$ BT - $100^{\circ} 41^{\prime} 12^{\prime \prime}$ BT dengan luas $57,64 \mathrm{~km}^{2}(0,14 \%$ dari luas Provinsi Sumatera Barat).

\section{Alat}

Alat yang digunakan pada penelitian ini adalah sebagai berikut:

1. Perangkat lunak Sublime untuk membuat dan mengedit script PHP, CSS, dan Java Script.

2. Perangkat lunak MS4W untuk memunculkan WebGIS melalui server localhost.

3. Perangkat lunak PostgreSQL untuk membuat dan mengedit basis data.

4. Perangkat lunak PostGIS untuk memproses data spasial.

\section{Bahan}

Bahan yang digunakan pada penelitian ini adalah sebagai berikut:

1. Peta zona nilai tanah Kota Solok tahun 2018 dalam format shapefile.

2. Google Maps API sebagai background peta zona nilai tanah.

3. Data Nilai Indikasi Rata-rata (NIR) Kota Solok tahun 2018.

4. Data Nilai Jual Objek Pajak (NJOP) Kota Solok tahun 2018.

\section{Tahapan Pembuatan WebGIS}

WebGIS zona nilai tanah Kota Solok merupakan webGIS yang diperuntukkan bagi Pemda, masyarakat, serta PPAT/Notaris. Dalam hal ini, masyarakat serta PPAT/Notaris merupakan pengguna, dimana dapat menghitung pajak yang harus dibayarkan saat terjadi transaksi jual beli tanah dan/atau bangunan, yaitu BPHTB serta PPh. Sedangkan Pemda merupakan administrator, selain dapat menghitung pajak seperti yang dapat dilakukan oleh masyarakat serta PPAT/Notaris, juga dapat memperbarui data NJOP Kota Solok. Berikut adalah tahapan pembuatan webGIS:

1. Mempersiapkan Data
Pada tahapan ini, terdapat dua data yaitu data spasial dan data nonspasial. Untuk data spasial, data peta zona nilai tanah yang telah didapatkan dikonversi ke dalam format geojson. Hal ini dilakukan agar data spasial dapat dipanggil nantinya melalui script khsusus. Sedangkan data nonspasial disimpan di dalam sebuah basis data dengan menggunakan perangkat lunak PostgreSQL.

2. Scripting

Pada tahapan scripting program yang dilakukan yaitu terbagi menjadi tiga bagian dimana semua bagian tersebut dibuat menggunakan program Sublime, antara lain sebagai berikut:

a. Scripting CSS untuk Tampilan WebGIS

Pada tahapan ini dilakukan pembuatan file CSS untuk mendesain tampilan dari WebGIS. Jenis file CSS yang digunakan yaitu CSS untuk desain halaman web serta CSS khusus Leaflet untuk desain tampilan peta.

b. Scripting Tag HTML

Pada tahapan ini dilakukan layouting untuk meletakkan beberapa tag yang dibutuhkan. Hal ini dilakukan agar tampilan dari WebGIS terlihat rapi dan estetis.

c. Scripting Fungsi Menggunakan Java Script dan PHP

Scripting fungsi dilakukan agar fitur-fitur yang disediakan dalam pembuatan WebGIS dapat dijalankan.

3. Menjalankan Hasil Scripting

Pada tahapan ini dilakukan pengujian apakah dari script yang telah dibuat dapat dijalankan melalui server localhost menggunakan perangkat lunak MS4W. Jika program dapat dijalankan maka dapat dilanjutkan ke proses selanjutnya. Jika tidak dapat dijalankan maka dapat dinyatakan bahwa script yang telah dibuat masih memiliki kesalahan. Hasil akhir dari tahapan ini yaitu fitur utama dan fitur pendukung webGIS dapat muncul di halaman peta.

4. Uji Fitur

Setelah hasil scripting dapat dijalankan, langkah selanjutnya yaitu melakukan pengujian setiap fitur. Fitur utama meliputi pencarian data, pengolahan data, dan 
pembaruan data. Sedangkan fitur pendukung meliputi zooming, dan pop up.

\section{HASIL DAN PEMBAHASAN}

\section{Analisis Hasil WebGIS}

WebGIS zona nilai tanah yang berhasil dibuat memiliki kemampuan sebagai berikut:

1. Menampilkan peta zona nilai tanah Kota Solok seperti nama kecamatan, nama kelurahan, Nilai Jual Objek Pajak (NJOP), serta Nilai Indikasi Rata-rata (NIR).

2. Memungkinkan transaksi data seperti pencarian data dan pembaruan data.

3. Menghitung pajak dalam jual beli tanah dan/atau bangunan yaitu Bea Perolehan Hak atas Tanah dan Bangunan (BPHTB) serta Pajak Penghasilan (PPh).

Tampilan menu webGIS ini terdiri dari halaman beranda, halaman peta online umum, dan halamn peta online administrator. Dimana halaman peta online umum ditujukan kepada masyarakat umum, sedangkan halaman peta online administrator ditujukan kepada pemda. Perbedaan dari kedua halaman tersebut adalah halaman peta online administrator mempunyai fitur untuk memperbarui NJOP.

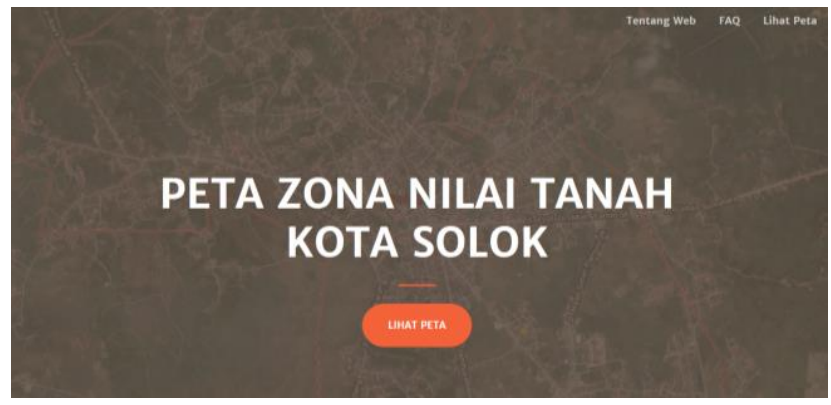

Gambar 2. Tampilan Awal Halaman Beranda

A. Halaman Beranda

Halaman beranda yang berdiri berdasarkan file index.php merupakan halaman utama dari website karena untuk dapat mengakses halaman lain pengguna harus terlebih dahulu membuka halaman beranda. Tampilan awal halaman beranda dapat dilihat pada gambar 2. Pada gambar dapat dilihat bahwa halaman beranda terdiri dari dari tiga menu yaitu menu
"Tentang Web", "FAQ", dan "Lihat Peta". Untuk menuju ketiga menu tersebut dapat langsung melakukan scroll ke bawah atau klik menu pada menu bar yang terdapat di bagian kanan atas halaman. Berikut merupakan tampilan menu bar yang terdapat pada halaman beranda.

\section{Tentang Web FAQ Lihat Peta}

Gambar 3. Menu Bar Halaman Beranda

Berikut merupakan script pembuatan menu bar:

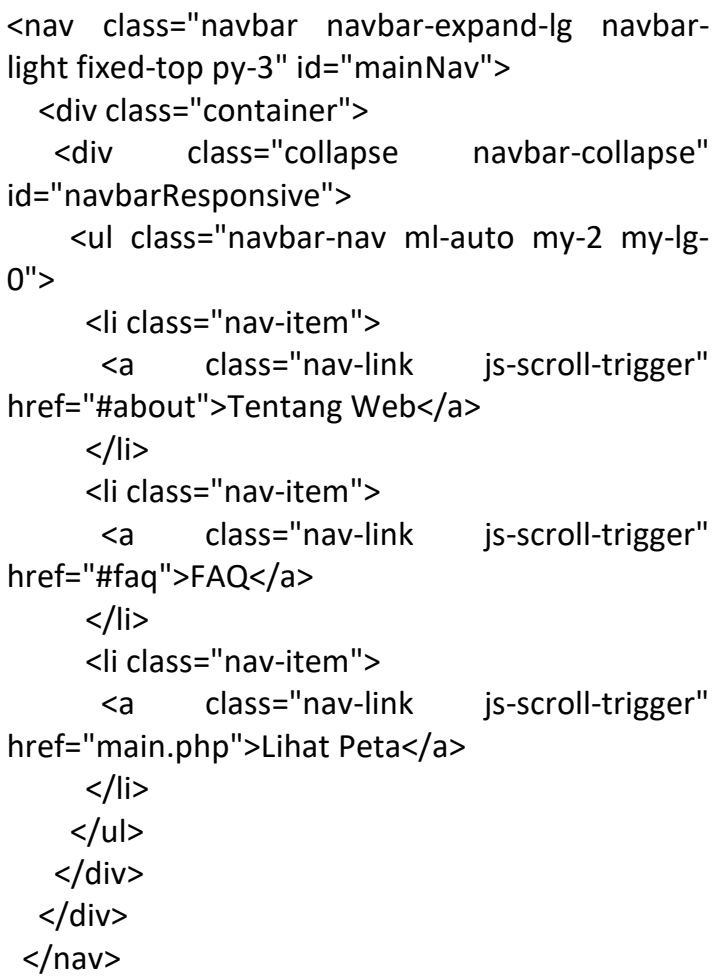

a. Menu Tentang Web

Menu tentang web berisi informasi mengenai fitur web dengan bahasa yang mudah dipahami oleh masyarakat umum. Pada menu ini terdapat pula tombol untuk langsung menuju halaman peta online umum. Berikut merupakan tampilan menu tentang web. 


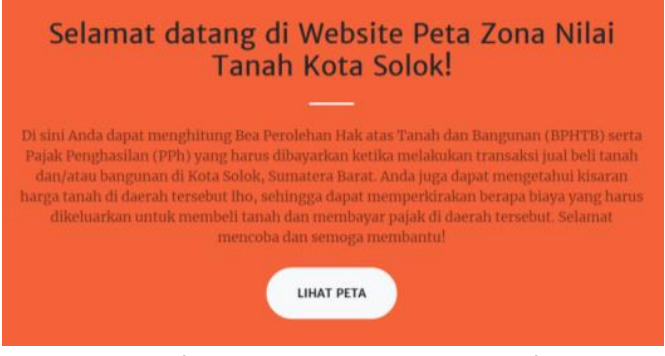

Gambar 4. Menu Tentang Web

b. Menu FAQ

Menu FAQ atau Frequently Asked Question berisi pertanyaan-pertanyaan yang kemungkinan akan sering ditanyakan oleh pengguna. Terdapat enam pertanyaan pada FAQ webGIS ini, dan salah satu diantaranya berisi cara penggunaan website. Berikut merupakan tampilan menu FAQ.

Apa yang dimaksud dengan Zona Nilai Tanah?
Apa yang dimaksud dengan NJOP?
Apa yang dimaksud dengan BPHTB?
Apa yang dimaksud dengan PPh?
Siapa yang dapat menggunakan website ini?
Bagaimana cara menggunakan website ini?
Gambar 5 Menu FAQ

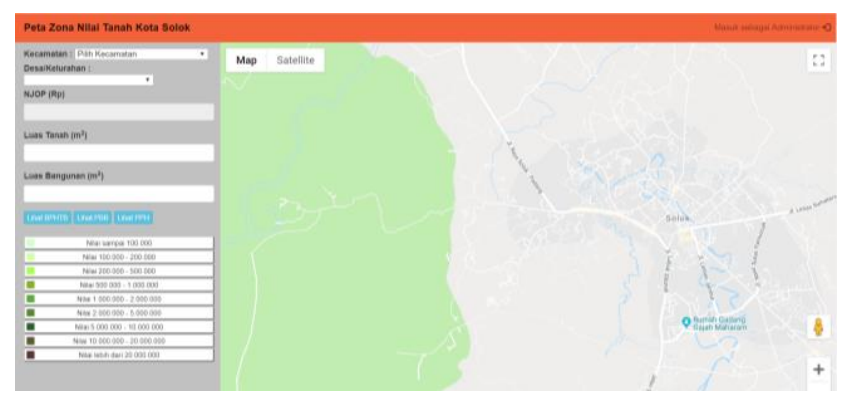

Gambar 5. Tampilan Awal Halaman Peta Online Umum

Halaman peta online umum dan halaman peta online administrator menggunakan Google MAPS API sebagai background halaman. Berikut merupakan script untuk menampilkan Google Maps API:

$<$ script src="https://maps.googleapis.com/maps/api/js ?v=3\&key=AlzaSyDKZ_EO7i_GnSTbyGarNz8g1c $6 \mathrm{Jq} \mid \mathrm{Xch} 04 \&$ libraries $=$ geometry\&callback $=\mathrm{fnToR}$ unWhenAPILoaded" $><$ /script $>$
B. Halaman Peta Online Umum

Halaman peta online umum yang berdiri dari file main.php dapat diakses melalui menu "Lihat Peta" pada halaman beranda. Tampilan halaman peta online umum dapat dilihat pada gambar 5. Pada gambar 5 dapat dilihat bahwa halaman peta online umum terdiri dari bagian navigation bar, side bar, dan juga maps. Pada navigation bar terdapat tombol "Masuk sebagai Administrator" untuk masuk ke halaman peta online administrator. Berikut merupakan tampilan tombol masuk sebagai administrator.

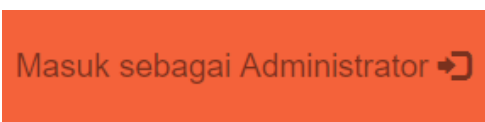

Gambar 6. Tombol Masuk sebagai Administrator

Berikut merupakan script pembuatan menu log in:

require('config.php');

if (isset(\$_POST['login_user'])) \{

Supwd = \$con-

>escapeString(\$_POST['password']);

echo \$con->userLogin(\$upwd); \}

Pada side bar terdapat menu-menu utama dari website. Berikut merupakan menumenu pada halaman peta online umum.

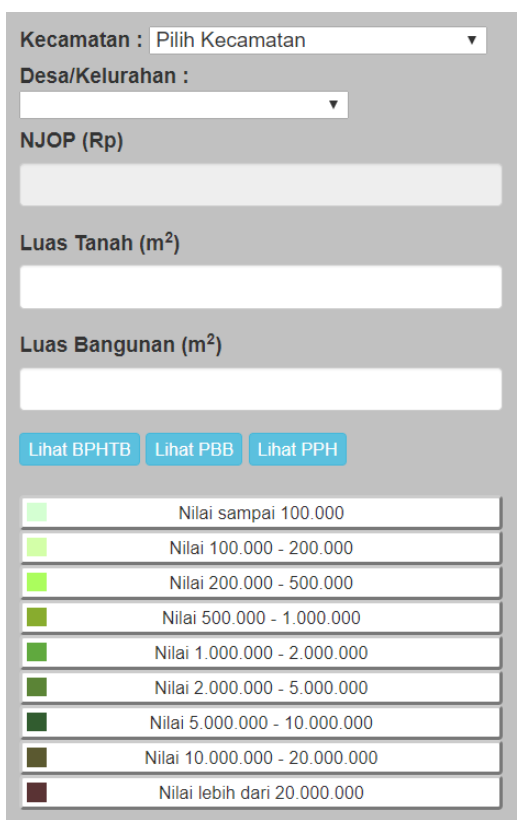

Gambar 7. Menu-Menu pada Halaman Peta Online Umum 
Gambar 7 merupakan menu-menu pada halaman peta online umum yang terdiri dari:

1. Menu Kecamatan.

Menu ini berfungsi untuk memilih kecamatan yang diinginkan, terdapat dua kecamatan di Kota Solok, yaitu Kecamatan Lubuk Sikarah dan Kecamatan Tanjung Harapan. Berikut merupakan script pembuatan menu kecamatan:

$<$ b $>$ Kecamatan $:</$ b $>$

$<$ select id="inputname" style="width: 70\%;" required>

<option value="' selected disabled $>$ Pilih Kecamatan</option>

<option value="LUBUK SIKARAH">LUBUK SIKARAH</option>

<option value="TANJUNG

HARAPAN">TANJUNG HARAPAN</option> $<$ select $>$

2. Menu Kelurahan.

Menu ini berfungsi untuk memilih kelurahan yang diinginkan, terdapat tujuh kelurahan di Kecamatan Lubuk Sikarah, dan enam kelurahan di Kecamatan Tanjung Harapan. Berikut merupakan script pembuatan menu kecamatan:

$<b>$ Desa/Kelurahan $:</$ b $>$

$<$ select id="starts" required $>$

$<$ option value="'" disabled $>$ Pilih Kecamatan terlebih dahulu</option>

$</$ select $>$

3. Menu NJOP.

Menu ini berfungsi untuk menampilkan NJOP dari zona nilai tanah yang telah dipilih pada bagian maps. Berikut merupakan script pembuatan menu NJOP:

$<$ div class="form-group" > $<$ label for="name">NJOP

$(\mathrm{Rp})</$ label $>$

<input id="form-njop" type="text" name="njop" readonly value="" class="form-control input-sm"/> $</$ div $>$

4. Menu Luas Tanah.

Menu ini berfungsi untuk memasukkan luas tanah yang terdapat di suatu zona nilai tanah yang ingin dihitung nilai pajaknya. Berikut merupakan script pembuatan menu luas tanah:

$<$ div class="form-group">

$<$ label for="name" $>$ Luas Tanah

( $m<$ sup $>2</$ sup $>$ ) $<$ /label $>$

$<$ input id="form-tanah" type="text" name="tanah" required value="" class="formcontrol input-sm"/>

$</$ div $>$

5. Menu Luas Bangunan.

Menu ini berfungsi untuk memasukkan luas bangunan yang terdapat di suatu zona nilai tanah yang ingin dihitung nilai pajaknya. Berikut merupakan script pembuatan menu luas bangunan:

<div class="form-group">

$<$ label for="name" $>$ Luas Bangunan ( $m<$ sup $>2</$ sup $>$ ) $<$ /label $>$

$<$ input id="form-bgn" type="text" name="bgn" required value="" class="formcontrol input-sm"/> $</$ div>

6. Menu Lihat BPHTB.

Menu ini berfungsi untuk menghitung nilai BPHTB yang harus dibayarkan saat terjadi transaksi beli tanah dan/atau bangunan. Berikut merupakan script pembuatan menu lihat BPHTB:

$<$ div class="form-group">

<input type="submit" name="bphtb" class="btn btn-info btn-xs" value="Lihat BPHTB" />

$</$ div>

7. Menu Lihat PPh.

Menu ini berfungsi untuk menghitung nilai PPh yang harus dibayarkan saat terjadi transaksi jual tanah dan/atau bangunan. Berikut merupakan script pembuatan menu lihat PPh:

$<$ div class="form-group">

$<$ input type="submit" name="pph" class="btn btn-info btn-xs" value="Lihat PPH" />

$</$ div $>$

8. Menu Rentang NJOP.

Menu ini berfungsi untuk memilih zona nilai tanah dengan NJOP pada rentang tertentu. Berikut merupakan script pembuatan menu salah satu rentang NJOP:

$<$ div class="input-color">

$<$ button class="btn-default btn-clr btn-xs" type="text" style="width:100\%" value $=" 0 ">$ Nilai sampai $100.000<$ /button> 
$<$ div class="color-box" style="backgroundcolor: \#d4ffd2;" $></$ div $>$ $</$ div $>$

Fungsi yang terdapat pada halaman peta online umum adalah fungsi pencarian data dan fungsi penghitungan BPHTB serta PPh. Berikut merupakan skema dari fungsi-fungsi tersebut.

1. Pencarian Data

Untuk pencarian data oleh pengguna dapat disesuaikan dengan kecamatan serta kelurahan yang akan dipilih. Berikut merupakan skema pencarian data. Gambar 8 menunjukkan skema pencarian data Kelurahan Aro IV Korong, Kecamatan Lubuk Sikarah.

Selain itu, dapat pula dilakukan pencarian data berdasarkan rentang NJOP. Berikut merupakan skema pencarian data berdasarkan rentang NJOP, dimana sebelumnya harus memilih minimal kecamatan terlebih dahulu seperti skema di atas. Gambar 9 menunjukkan skema pencarian data Kelurahan Aro IV Korong, Kecamatan Lubuk Sikarah dengan rentang NJOP $500.000-1.000 .000$.

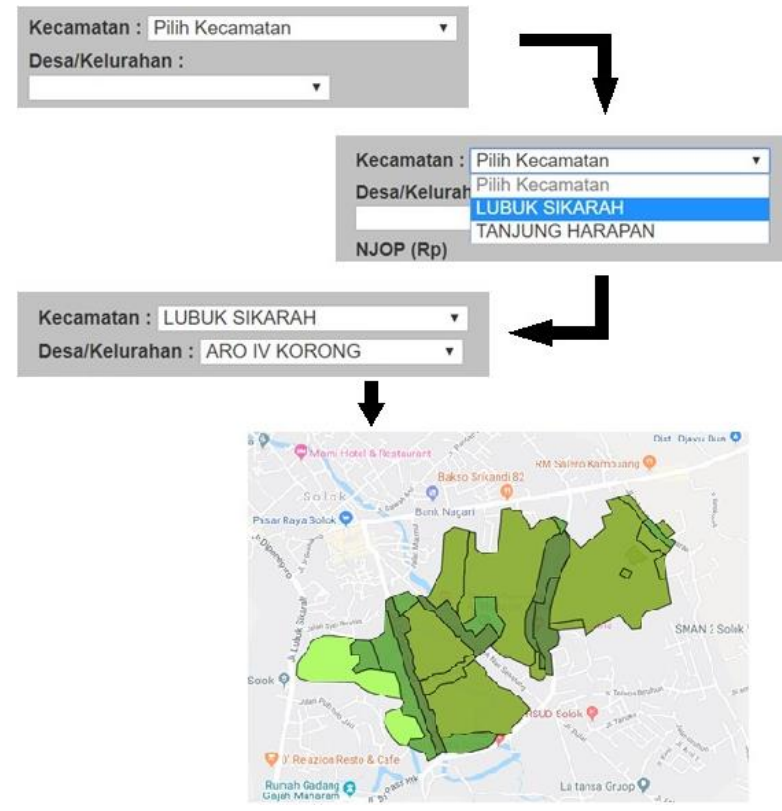

Gambar 8. Skema Pencarian Data

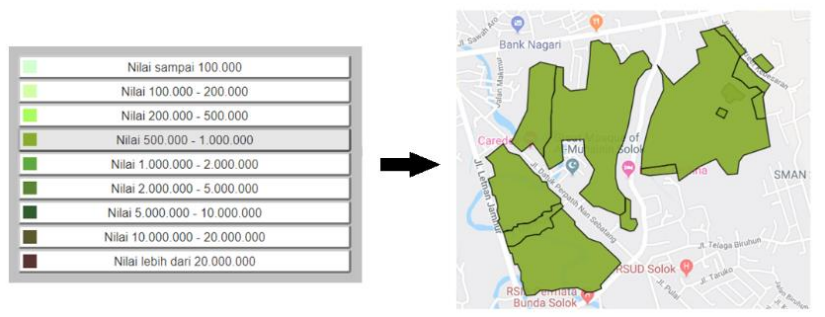

Gambar 9. Skema Pencarian Data Berdasarkan Rentang

Untuk menampilkan NJOP dan NIR dari suatu zona nilai tanah, setelah melakukan pencarian data seperti yang telah dijelaskan pada skema pencarian data, dapat langsung memilih zona nilai tanah yang diinginkan. Berikut merupakan informasi suatu zona nilai tanah yang ditampilkan dalam pop up.

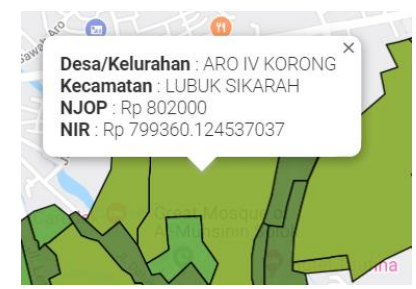

Gambar 10. Pop Up Informasi Zona Nilai Tanah

Berikut merupakan script pembuatan pop up:

var createlnfoWindow_p = function(polygon, nama, q2, njop, gid, myLatlng, nir, tanah, bgn)\{ infowindow = new google. maps. InfoWindow(); google.maps.event.addListener(polygon, 'click', function(event)\{

infowindow.close();

infowindow.setContent(" $<b>$ Desa/Kelurahan $</ b>$ : $\quad$ "+nama+" $<$ br $><b>$ Kecamatan $</$ b $>\quad:$ "+inputname2.value+" $\langle\mathrm{b} r><b>\mathrm{NJOP}</ \mathrm{b}>\quad: \quad \mathrm{Rp}$ "+njop+" $<$ br $><b>N I R</ b>\quad: \quad R p$ "+nir+" $<$ br $><$ b $>$ Luas Tanah $</$ b $>$ : "+tanah+" m $<$ sup $>2</$ sup $\rangle\langle$ br $><$ b $>$ Luas Bangunan $</$ b $>$ : "+bgn+" m<sup $>2<$ (sup $>$ ");

\section{Penghitungan BPHTB dan PPh}

Untuk penghitungan BPHTB dan PPh oleh pengguna dapat dilakukan dengan memilih zona nilai tanah yang diinginkan kemudian memasukkan luas tanah dan luas bangunan. Setelah itu, tekan tombol "Lihat BPHTB" atau "Lihat PPh", sesuai dengan jenis pajak yang ingin dihitung. Berikut merupakan skema pencarian data. Gambar 11 menunjukkan 
skema penghitungan BPHTB pada suatu zona nilai tanah di Kelurahan Aro IV Korong, Kecamatan Lubuk Sikarah dengan luas tanah $100 \mathrm{~m}^{2}$ serta luas bangunan 0 $\mathrm{m}^{2}$.

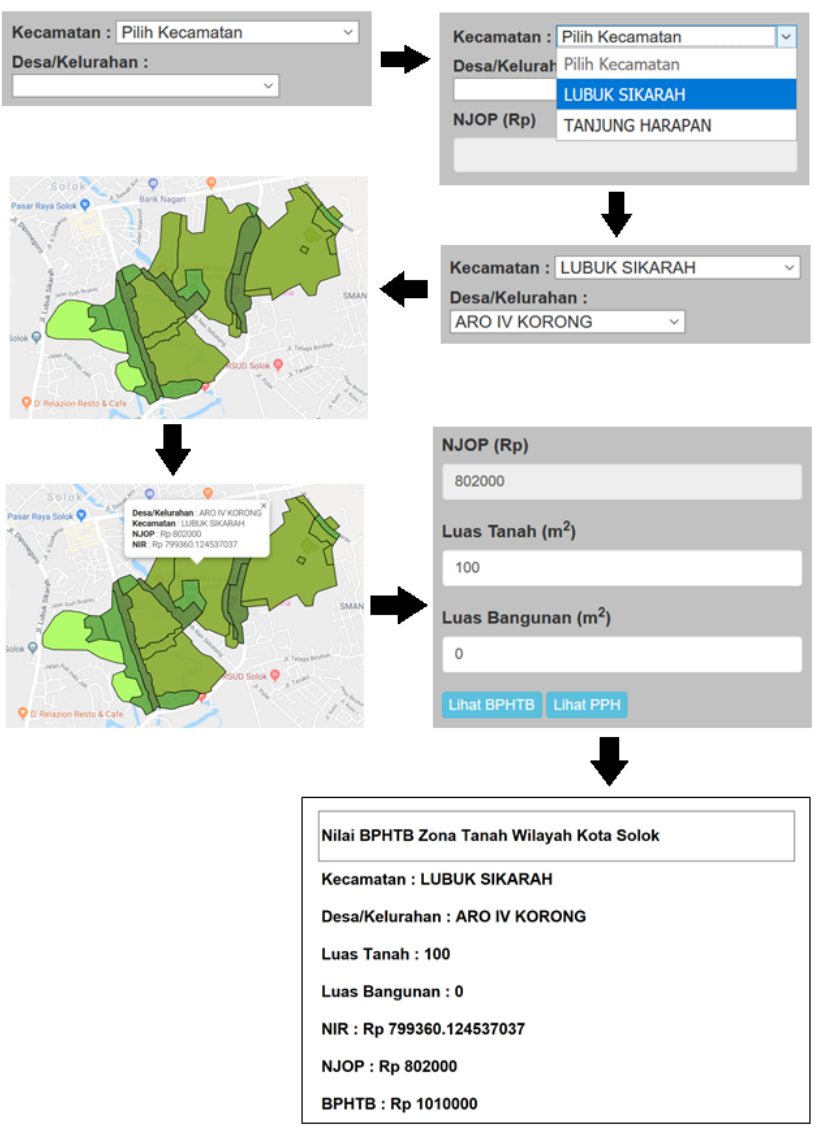

Gambar 11. Skema Penghitungan Pajak

Fungsi penghitungan pajak berjalan dalam file update.php. Berikut merupakan script pembuatan fungsi penghitungan pajak:

BPHTB:

$\$ p d f=$ new FPDF();

\$pdf->AliasNbPages();

$\$$ pdf->AddPage();

\$pdf- $>$ SetFont('Helvetica',' $B$ ',18);

$\$$ pdf->Cell $(0,20, " N i l a i \quad B P H T B \quad Z$ Zna Tanah

Wilayah Kota Solok",1,1);

\$bphtb

$5 / 100 *(((\$$ POST['tanah'] $+\$$ POST['bgn'] $) *$ \$_P

OST['njop'])-60000000);

PPh:

$\$ p d f=$ new FPDF();

$\$$ pdf->AliasNbPages();

$\$$ pdf->AddPage();

$\$$ pdf->SetFont('Helvetica','B',18);

$\$$ pdf->Cell $(0,20, " N i l a i$ PPH Zona Tanah Wilayah

Kota Solok",1,1);
$\$ p p h$ $=$

25/1000*((\$_POST['tanah'] +\$_POST['bgn'])*\$_P OST['njop']);

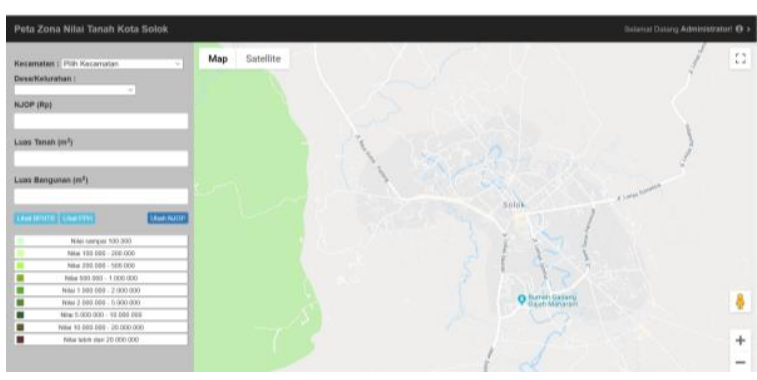

Gambar 12. Tampilan Halaman Peta Online Administrator

C. Halaman Peta Online Administrator

Halaman peta online administrator yang dibangun pada file dashboard.php dapat diakses dengan menekan tombol "Masuk sebagai Administrator" yang terdapat pada navigation bar halaman peta online umum, kemudian mengisi password yang sebelumnya akan diberitahukan kepada administrator. Pada webGIS ini, administrator yang dimaksud adalah Pemda, dimana Pemda dapat menganti NJOP pada suatu zona nilai tanah. Tampilan halaman peta online administrator dapat dilihat pada gambar 12. Pada gambar 12 dapat dilihat bahwa halaman peta online administrator terdiri dari bagian navigation bar, side bar, dan juga maps. Pada navigation bar terdapat tombol "Log Out" untuk keluar dari halaman peta online administrator. Berikut merupakan tampilan tombol log out.

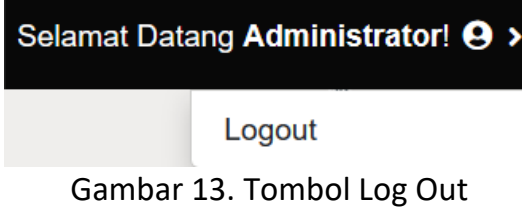

Berikut merupakan script pembuatan menu log out:

@session_start();

include_once('config.php');

\$con->userLogout();

header('Location: main.php');

Pada side bar terdapat menu-menu utama dari website. Perbedaan dengan menu pada halaman peta online umum adalah menu 
"Ubah NJOP" untuk melakukan pembaruan NJOP. Selain itu, fungsi peta online administrator dan peta online umum hanya pada fungsi pembaruan data. Berikut merupakan skema pembaruan data:

Pembaruan data NJOP dapat dillakukan dengan cara mengganti nominal pada menu "NJOP", kemudian menekan tombol "Ubah NJOP". Berikut merupakan skema pembaruan data. Gambar 15 menunjukkan skema pembaruan data NJOP suatu zona nilai tanah di Kelurahan Aro IV Korong, Kecamatan Lubuk Sikarah.

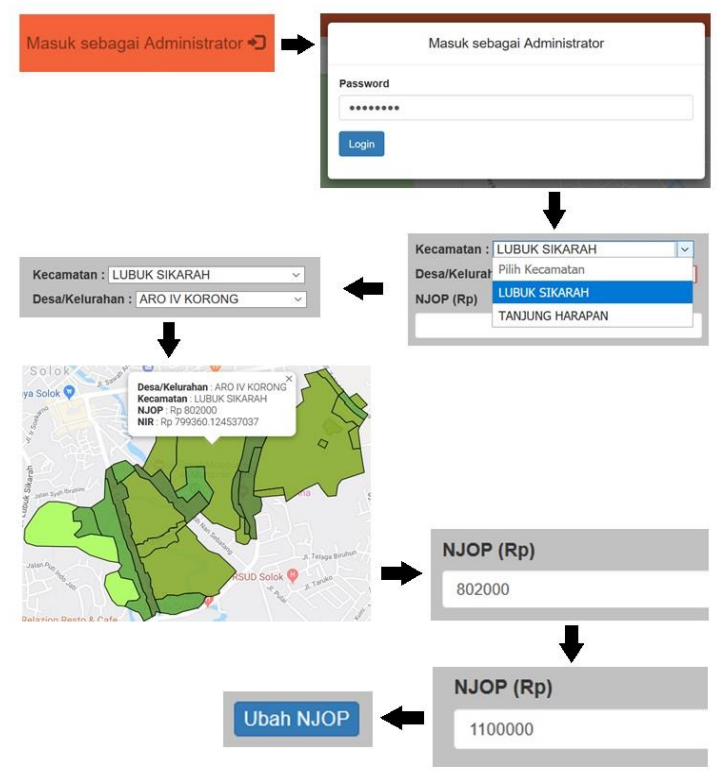

Gambar 14. Skema Pembaruan Data

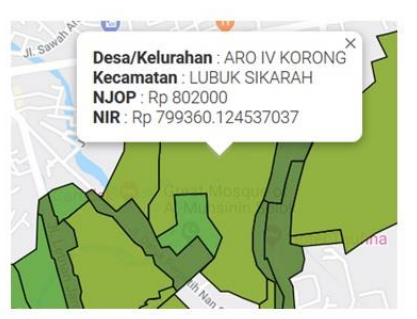

Sebelum

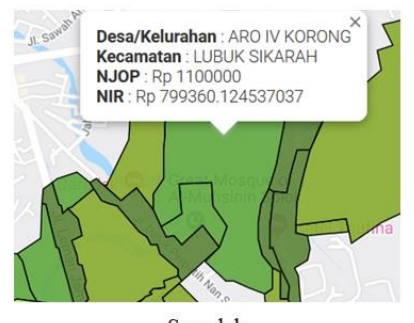

Sesudah
Gambar 15. Zona Nilai Tanah Sebelum dan Sesudah pembaruan Data

Gambar 15 menunjukkan zona nilai tanah sebelum dan sesudah dilakukan pembaruan data NJOP, dapat dilihat data NJOP yang ditampilkan pada pop up sudah berubah, begitu pula dengan warna data spasial sudah berubah mengikuti rentang NJOP yang terdapat pada side bar.

\section{Uji Usabilitas}

Uji usabilitas dilakukan berdasarkan hasil penilaian pengguna setelah mengunjungi webGIS zona nilai tanah dan mengisi kuisioner. Pertanyaan yang terdapat dalam kuisioner mewakili 5 aspek uji usabilitas yaitu kemudahan untuk dipelajari, efisiensi, mudah diingat, kesalahan, dan kepuasan. Dimana terdapat 5 pertanyaan dari masing-masing aspek. Hasil uji kebergunaan ini diperoleh berdasarkan 35 orang responden. Berdasarkan perhitungan presentase kelayakan, didapatkan presentase sebesar $80,38 \%$ sehingga web termasuk kategori layak.

\section{Uji Portabilitas}

Uji portabilitas yang dilakukan yaitu mencoba menjalankan sistem ke beberapa web browser. Dalam hal ini, web browser yang digunakan yaitu web browser untuk personal computer. Dalam pengujian portabilitas, web zona nilai tanah ini dapat berjalan dengan baik di sepuluh web browser yaitu Google Chrome, Opera, Internet Explore, Mozilla Firefox, UC Browser, Microsoft Edge, Comodo Dragon, Maxthon, Vivaldi, dan Brave.

\section{KESIMPULAN}

WebGIS ona nilai tanah Kota Solok telah berhasil dibuat dengan beberapa fitur utama yaitu pencarian zona nilai tanah, input luas tanah dan luas bangunan, penghitungan pajak BPHTB dan PPh, ekspor hasil penghitungan pajak dalam bentuk PDF, log in sebagai administrator, pambaruan data NJOP, FAQ, pop up, dan zooming. Besar persentase kelayakan sistem untuk uji usabilitas sebesar $80,38 \%$ dengan predikat baik dan melakukan uji portabilitas dengan mengakses webGIS zona nilai tanah Kota Solok di sepuluh web browser dan berhasil.

\section{UCAPAN TERIMA KASIH}

Penulis mengucapkan terima kasih kepada semua pihak yang telah membantu penelitian ini terutama PT. Geomosaic Indonesia yang telah memberikan dukungan berupa data zona nilai tanah baik data spasial maupun non spasial. 


\section{DAFTAR PUSTAKA}

BPS Kota Solok. 2018. Kota Solok dalam Angka 2018. Kota Solok: BPS Kota Solok.

Direktorat Jenderal Pajak. 2012. Belajar Pajak. April. http://www.pajak.go.id/content/belajar-pajak.

Kertopati, P. 2015. Strategi Pemerintah DKI Jakarta dalam Rangka Optimalisasi Penerimaan Bea Perolehan Hak atas Tanah dan Bangunan (BPHTB).
Surabaya: Fakultas Ekonomi dan Bisins Perbanas Institute.

Sutawijaya, A. 2004. Analisis Faktor-Faktor yang Mempengaruhi Nilai Tanah sebagai Dasar Penilaian Nilai Jual Obyek Pajak (NJOP) PBB di Kota Semarang. Semarang: Fakultas Ekonomi Universitas Terbuka.

Website Resmi Kota Solok. 2019. Letak Geografis. Januari.

http://www.solokkota.go.id/index.php/profil/potens i/letak-geografis. 